\title{
COMPUTERIZED INSTRUCTION AND THE LEARNING PROCESS
}

BY

RICHARD C. ATKINSON

TECHNICAL REPORT NO. 122

September 15,1967

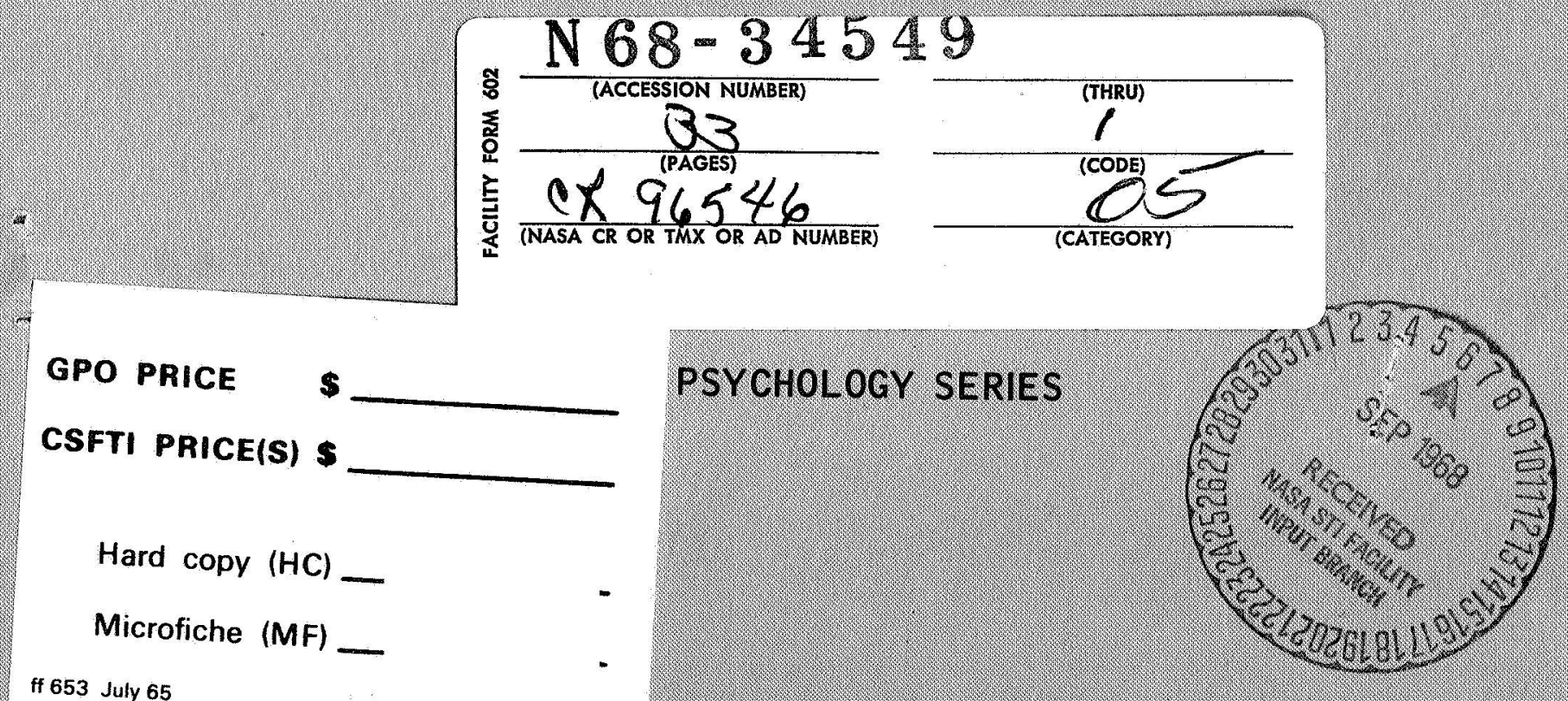

INSTITUTE FOR MATHEMATICAL STUDIES IN THE SOCIAL SCIENCES

STANFORD UNIVERSITY

STANFORD, CALIFORNIA 


\section{TECHNICAL REPORTS \\ PSYCHOLOGY SERIES \\ INSTITUTE FOR MATHEMATICAL STUDIES IN THE SOCIAL SCIENCES \\ (Place of publication shown in parentheses; if published title is different from title of Technical Report, this is also shown in parentheses.)}

1955. (Experimental test of the basic model, Chapter 2 in Decislon-making: An Experimental Apgroach. Stanford Univ. Press, 1957)

P. Suppes. Note on computing all optimal solutions of a dual linear programming problem. November 15, 1955.

3 D. Davidson and P. Suppes. Experimental measurement of utility by use of a linear programming model. April 2, 1956. (Experimental test of a linear programming model, Chapter 3 in Decision-making: An Experimental Approach. Stanford Univ. Press, 1957)

E. W. Adans and R. Fagot. A model of riskless choice. August 7, 1956. (Behavioral Sclence, 1959, 4, 1-10)

R. C. Atkinson. A comparison of three nodels for a Humphreys-type conditioning situation. Novembes 20, 1956.

D. Scott and P. Suppes. Foundational aspects of theories of measurement. April 1, 1957. (1. Symbolic Logic, 1958, 23, 113-128)

M. Gerlach. Interval measurement of subjective magnitudes with subliminal differences. Aprll 17, 1957.

R. C. Atkinson and P. Suppes. An analysis of two-person game situations in terms of statistical learning theory. April 25, 1957. W. exp. Psychol., 1958, 55, 369-378)

9 R. C. Atkins on and P. Suppes. An analysis of a two-person Interaction situation in terms of a Markov process. May 29, 1957. (ln R. R. Bush

and W. K. Estes (Eds.), Studies in Mathematical Learning Theory. Stanford Univ. Press, 1959, Pp. 65-75)

J. Popper and R. C. Atkinson. Discrimination learning in a verbal conditioning situation. July 15, 1957. U. exp. Psychol., 1958, 56, 21-26)

P. Suppes and K. Walsh. A non-tinear model for the experimental measurement of utility. August 21, 1956. Behavioral Science, 1959, 4, 204-211)

E. Adams and S. Messick. An axionatization of Thurstone's successive intervals and paired comparisons scaling models. September $9,1957$.

(An axiomatic formulation and generalization of successive intervals scaling, Psychometrika, 1958, 23, 355-368)

R. Fagot. An ordered metric model of individual choice behavior. September 12, 1957. (A model for ordered metric scaling by comparis on of

intervals. Psychometrika, 1959, 24, 157-168)

H. Royden, P. Suppes, and K. Walsh. A model for the experimental measurement of the utility of gambling. September 25, 1957. (Behavioral Science, 1959, 4, 11-18)

P. Suppes. Two formal models for moral principles. November $1,1957$.

W. K. Estes and P. Suppes, Foundations of statistical learning theory, I. The linear model for simple learning. November 20, 1957. (Foundations of linear models. In R. R. Bush and W. K. Estes (Eds.), Studies in Mathematical Learning Theory. Stanford Univ. Press, 1959. Pp. 137-179)

D. Davids on and J. Marshak. Experimental tests of a stochastic decision theory. July 25, 1958. (In C. W. Churchman and P. Ratoosh (Eds.), Measurement: Definition and Theories. New York: Wiley, 1959. Pp. 233-269)

J. Lamperti and P. Suppes. Chains of infinite order and their application to learning theory. October 15, 1958. (Pacific Journal of Mathematics 1959, 9, 739-754)

Suppes. Alinear learning model for a continuum of responses. October 18, 1958. (In R. R. Bush and W. K. Estes (Eds, ), Studies in

Mathematical Learning Theory. Stanford Univ. Press, 1959. Pp. 400-414)

. Suppes. Męasurement, empirical meaningfulness and three-valued logic. December 29, 1958. (in C. West Churchman and P. Ratoosh

(Eds.), Measurement: Definition and Theories. New York: Wiley, 1959, Pp. 129-143)

P. Suppes and R. C. Atkinson. Markov learning models for multiperson situations, 1.
Markov Learning Models for Multiperson Interaction. Stanford Univ. Press, 1960)

J. Lamperti and P. Suppes. Some asymptotic properties of Luce's beta learning model. April 24, 1959. (Psychometrika, 1960, 25, 233-241)

P. Suppes. Behavioristic foundations of utility. July 27, 1959. (Econometrica, 1961, 29, 186-202)

P. Suppes and F. Krasne. Application of stimulus sampling theory to situations involving social pressure. September 10, 1959. (Psychol. Rev., 1961, 68, 46-59)

P. Suppes. Stimulus sampling theory for a continuum of responses. September 11, 1959. (In K. Arrow, S. Karlin, and P. Suppes (Eds.), Mathematical Methods in the Social Sclences. Stanford Univ. Press, 1960. Pp. 348-365)

W, K. Estes and P. Suppes. Foundations of statistical learning theory, II. The stimulus sampling model. October 22, 1959.

P. Suppes and R. C. Atkinson. Markov learning models for multiperson situations, II. Methods of analysis. December 28, 1959: (Chapter 2

In Markov Learning Models for Multiperson Interactions. Stanford Univ. Press, 1960)

28 R. C. Atkinson. The use of models in experimental psychology. May 24, 1960. (Synthese, 1960, 12, 162-171)

29 R. C. Atkinson. A generalization of stimulus sampling theory. June 14, 1960. (Psychometrika, 1961, 26, 281-290)

P. Suppes and J. M. Carlsmith. Experimental analysis of a duopoly situation from the standpoint of mathematical learning theory. June $17,1960$. (International Economic Review, 1962, 3, 1-19)

31 G. Bower. Properties of the one-element model as applied to paired-associate learning. June 29, 1960. (Application of a model to pairedassociate learning, Psychometrika, 1961, 26, 255-280)

r. 32 J. H. Blau. The combining of classes condition in learning theory. August 23, 1960. (See Transformation of probabilities, Proceedings of the Amer. Math. Soc., 1961, 12, 511-518)

33 P. Suppes. A comparison of the meaning and uses of models in mathematics and the empirical sciences. August 25, 1960. (Synthese, 1960, 12, 287-301)

P. Suppes and J. Zinnes. Stochastic learning theories for a response continuum with non-determinate reioforcement. 0 ctober $25 ; 1960$. (Psychometrika, 1961, 26, 373-390)

35

P. Suppes and R. Ginsberg. Application of a stimulus sampling model to children's concept formation of binary numbers, with and without an

overt correction response. December 14, 1960. (Application of a stimulus sampling model to children's concept formation with and without an overt correction response, Journal exp. Psychol, 1962, 63, 330-336) 
COMPUTERIZED INSTRUCTION AND THE LEARNING PROCESS

by

Richard C. Atkinson

TECHNICAL REPORT NO 122

September 15, 1967

PSYCHOLOGY SERIES

Reproduction in whole or in Part is Permitted for any Purpose of the United States Government

INSTITUTE FOR MATHEMATICAL STUDIES IN THE SOCIAL SCIENCES

STANFORD UNIVERSITY

STANFORD, CALIFORNIA 
Computerized Instruction and the Learning Process ${ }^{1}$

\section{Richard C. Atkinson}

In recent years there has been a tremendous number of articles and news releases dealing with computer-assisted instruction (CAI). One might conjecture that this proliferation is an indicant of rapid progress in the field. Unfortunately, I doubt that it is. A few of the reports about CAI are based on substantial experience and research, but the majority are vague speculations and conjectures with little if any data or real experience to back them up. I do not want to underrate the role of speculation in a newly developing area like CAI. However, of late it seems to have produced little more than a repetition of ideas that were exciting in the $1950^{\prime} \mathrm{s}$ but, in the absence of new research, are becoming tiresome and misleading in the late $1960^{\prime} \mathrm{s}$.

These remarks should not be misinterpreted. Important and significant research on CAI is being conducted in many laboratories around the country, but certainly not as much as one is led to believe by the attendant publicity. The problem for someone trying to evaiuate developments in the field is to distinguish between those reports that are based on fact and those that are disguised forms of science fiction. In my talk today, I shall try to stay very close to data and actual experience. My claims will be less grand than many that have been made for CAI, but they will be based on a substantial research effort.

Invited address presented at meetings of the American Psychological Association, Washington, D.C., September, 1967 . 
In 1964 Patrick Suppes and I initiated a project under a grant from the Office of Education to develop and implement a CAI program in initial reading and mathematics. Because of our particular research interests, Suppes has taken responsibility for the mathematics curriculum and I have been responsible for the initial reading program. At the beginning of the project, two major hurdles had to be overcome. There was no lesson material in either mathematics or reading suitable for CAI, and an integrated CAI system had not yet been designed and produced by a single manufacturer. The development of the curricula and the development of the system have been carried out as a paraliel effort over the last three years with each having a decided influence on the other.

Today I would like to report on the progress of the reading program with particular reference to the past school year when for the first time a sizable group of children received a major portion of their daily reading instruction under computer control. The first year's operation must be considered essentially as an extended debugging of both the computer system and the curriculum materials. Nevertheless, some interesting comments can be made on the basis of this experience regarding both the feasibility of CAI and the impact of such instruction on the overall learning process.

Before describing the Stanford Project, a few general remarks may help place it in proper perspective. Three levels of CAI can be defined. Discrimination between levels is based not on hardware considerations, but principally on the complexity and sophistication of the student-system interaction. An advanced student-system interaction may be achieved with a simple teletype terminal and the most primitive intèráction may require si 
some highly sophisticated computer programming and elaborate student terminal devices.

At the simplest interactional level are those systems that present a fixed, linear sequence of problems. Student errors may be corrected in a variety of ways, but no real-time decisions are made for modifying the flow of instructional material as a function of the student"s response history. Such systems have been termed "drill-and-practice" systems and at Stanford University are exemplified by a series of fourth, fifth and sixth grade programs in arithmetic and language arts that are designed to supplement classroom instruction. These particular programs are being useed in several different areas of California and also in Kentucky and Mississippi, all under control of one central computer located at stanford University. Currently as many as 2000 students are being run per day; it requires little imagination to see how such a system could be extended to cover the entire country. Unfortunately, I do not have time to discuss these drill-and-practice programs today, but there are several recent reports describing the research (Suppes, 1966; Suppes, Jerman, and Groen, 1966; Fishman, Keller, and Atkinsonn, 1967).

At the other extreme of our scale characterizing student-system interactions are "dialogue" programs. Such programs are under investigation at several universities and industrial concerns, but to date progress has been extremely limited. The goal of the dialogue approach is to provide the richest possible student-system interaction where the student is free to construct natural-language responses, ask questions in an unrestricted mode, and in general exercise almost complete control over the sequence of learning events. 
"Tutorial" programs lie between the above extremes of student-system interaction. Tutorial programs have the capability for real-time decisionmaking and instructional branching contingent on a single response or on some subset of the student's response history. Such programs allow students to follow separate and diverse paths through the curriculum based on their particular performance records. The probability is high in a tutorial program that no two students will encounter exactly the same sequence of lesson materials. However, student responses are greatly restricted since they must be chosen from a prescribed set of responses, or constructed in such a manner that a relatively simple text analysis will be sufficient for their evaluation. The CAI Reading Program is tutorial in nature and it is this level of student-system interaction that I want to talk about today.

\section{The Stanford CAI System}

The Stanford Tutorial System was developed under a contract between Stanford University and the IBM Corporation. Subsequent developments by IBM of the basic system have led to what has been designated the IBM-I500 Instructional System which should soon be commercially available. The basic system consists of a central process computer with accompanying discstorage units, proctor stations, and an interphase to 16 student terminals. The central process computer acts as an intermediary between each student and his particular course material which is stored in one of the discstorage units. A student terminal consists of a picture projector, a cathode ray tube (CRT), a light-pen, a modified typewriter keyboard, and an audio system which can play pre-recorded messages. 


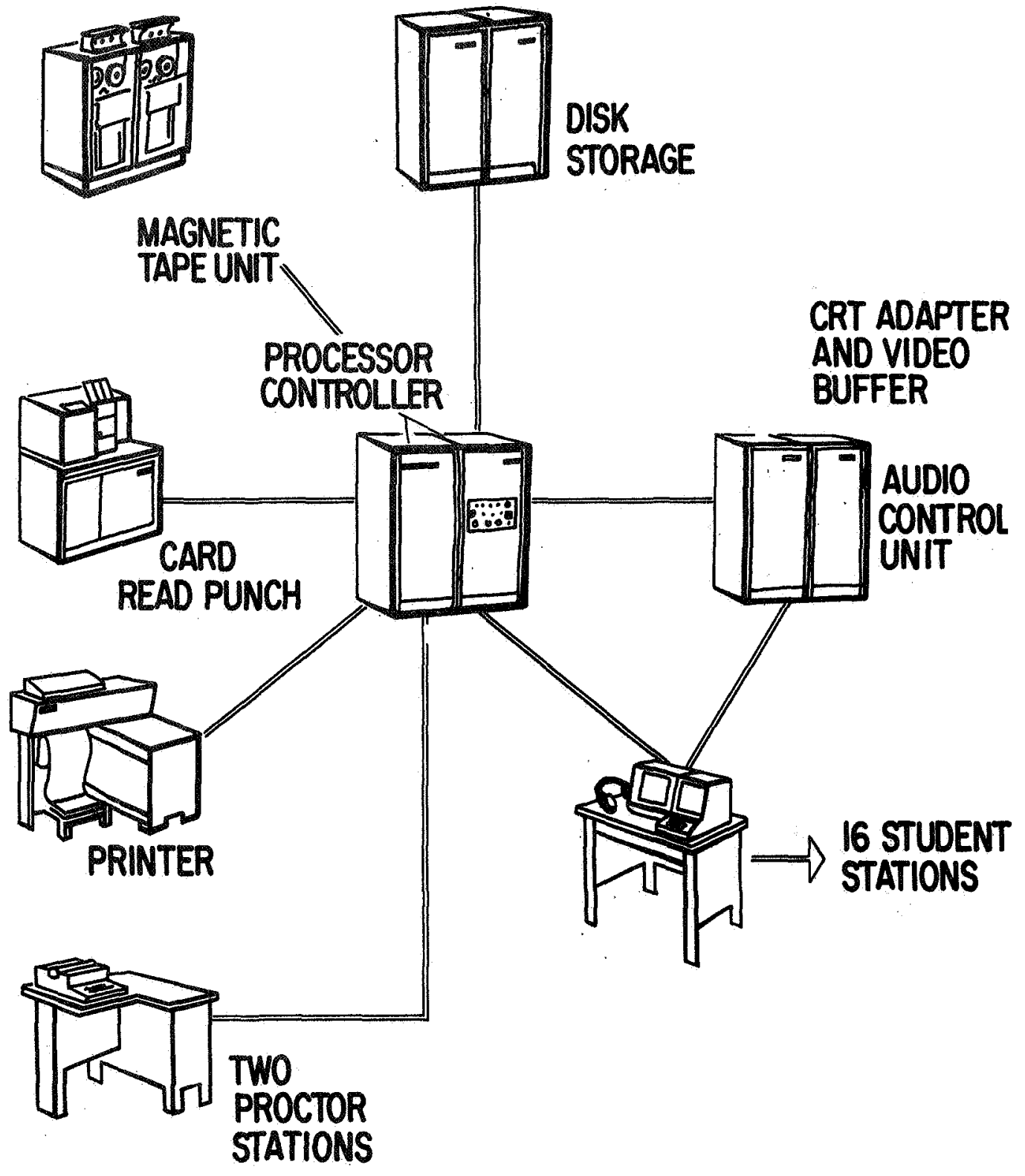

Figure 1. System configuration for Stanford CAI System. 
The CRT is essentially a television screen on which alpha-numeric characters and a limited set of graphics ( $i_{\circ} e_{\circ}$, simple line drawings) can be generated under computer control. The film projector is a rear-view projection device which permits us to display still pictures in black and white or color. Each film strip is stored in a self-threading cartriage and contains over 1000 images which may be accessed very quickly under computer control. The student receives audio messages via a high-speed device capable of selecting any number of messages varying in length from a few seconds to over 15 minutes. The audio messages are stored in tape cartridges which contain approximately two hours of messages and, like the film cartridge, may be changed very quickly. To gain the student's attention, an arrow can be placed at any point on the CRT and moved in synchronization with an audio message to emphasize given words or phrases, much like the "bouncing ball" in a singing cartoon.

The major response device used in the reading program is the light pen, which is simply a light-sensitive probe. When the light pen is placed on the CRT, coordinates of the position touched are sensed as a response and recorded by the computer. Responses may also be entered into the system through the typewriter keyboard. However, only limited use has been made of this response mode in the reading program. This is not to minimize the value of keyboard responses, but rather to admit that we have not as yet addressed ourselves to the problem of teaching first-grade children to handle a typewriter keyboard.

The CAI System controls the flow of information and the input of student responses according to the instructional logic built into the curriculum. The sequence of events is roughly as follows: The computer assembles 
the necessary commands for a given instructional sequence from a discstorage unit. The commands involve directions to the terminal device to display a given sequence of symbols on the CRT, to present a particular image on the film projector, and to play a specific audio message. After the appropriate visual and auditory materials have been presented, a "ready" signal indicates to the student that a response is expected. Once a response has been entered, it is evaluated and, on the basis of this evaluation and the student's past history, the computer makes a decision as to what materials will subsequently be presented. The time-sharing nature of the system allows us to handle 16 students simultaneously and to cycle through these evaluative steps so rapidly that from a student's viewpoint it appears that he is getting immediate attention from the computer whenever he inputs a response.

The CAI Reading Curriculum

The flexibility offered by this computer system is of value only if the curriculum materials make sense both in terms of the logical organization of the subject matter and the psychology of the learning processes involved. Time does not permit a discussion of the rationale behind the curriculum materials that we have developed. Let me simply say that our approach to initial reading can be characterized as applied psycholinguistics. Hypotheses about the reading process and the nature of learning to read have been formulated on the basis of linguistic information, observations of language use, and an analysis of the function of the written code. These hypotheses have been tested in a series of pilot studies structured to simulate actual teaching situations. On the basis of these experimental findings, the hypotheses have been modified, retested, and 
ultimately incorporated into the curriculum as principles dictating the format and flow of the instructional sequence. Of course, this statement is somewhat of an idealization, since very little curriculum material can be said to have been the perfect end-product of rigorous empirical evaluation. We would claim, however, that the fundamental tenets of the Stanford reading program have been formulated and modified on the basis of considerable empirical evidence. There is no doubt that these will be further modified as more data accumulates.

The instructional materials are divided into eight levels each composed of about 32 lessons. ${ }^{2}$ The lessons are designed so that the average student will complete one in approximately 30 minutes, but this can vary greatly with the fast student finishing much sooner and the slow student sometimes taking two hours or more if he hits most of the remedial material. Within a lesson, the various instructional tasks can be divided into three broad areas: 1) decoding skills, 2) comprehension skills, 3) games and other motivational devices. Decoding skills involve such tasks as letter and letter-string identification, word list learning, phonic drills, and related types of activities. Comprehension involves such tasks as having the computer read to the child or having the child himself read sentences, paragraphs or complete stories about which he is then asked a series of questions. The questions deal with the direct recall of facts, generalizations about main ideas in the story, and inferential questions which require the child to relate information presented in the story to his own experience. Finally, many different types of games are sequenced into the lessons primarily to encourage continued attention to the materials.

${ }^{2}$ For a detailed account of the curriculum materials see Rodgers (1967) and Wilson and Atkinson (1967). See also Atkinson (1967), Atkinson and Hansen (1966) and Hansen and Rodgers (1965)。 
The games are similar to those played in the classroom and are structured to evaluate the developing reading skills of the child.

To give you some feel for the instructional materials, let me describe one of the decoding tasks. This task which goes by the title "matrix construction" provides practice in learning to associate orthographically similar sequences with appropriate rhyme and alliteration patterns. Rhyming patterns are presented in the columns of the matrix and alliteration patterns are presented in the rows of the matrix as illustrated in the lower left-hand panel of Figure 4.

The matrix is constructed one cell at a time. The initial consonant of a CVC word is termed the initial unit and the vowel and the final consonant are termed the final unit. The intersection of an initial unit row and a final unit column determines the entry in any given cell.

The problem format for the construction of each cell is divided into four parts: Parts $A$ and $D$ are standard instructional sections and Parts $B$ and $C$ are remedial sections. The flow diagram in Figure 2 indicates that remedial Parts $B$ and $C$ are branches from Part $A$ and may be presented independently or in combination.

To see how this goes, let us consider the example illustrated in Figure 3. The student first sees on the CRT the empty cell with its associated initial and final units and an array of response choices. He hears the audio message indicated by response request I (RR I) in Part A of Figure 3. If the student makes the correct response (CA) (i.e., touches ran with his light pen) he proceeds to Part $D$ where he sees the word written in the cell and receives one additional practice trial. 


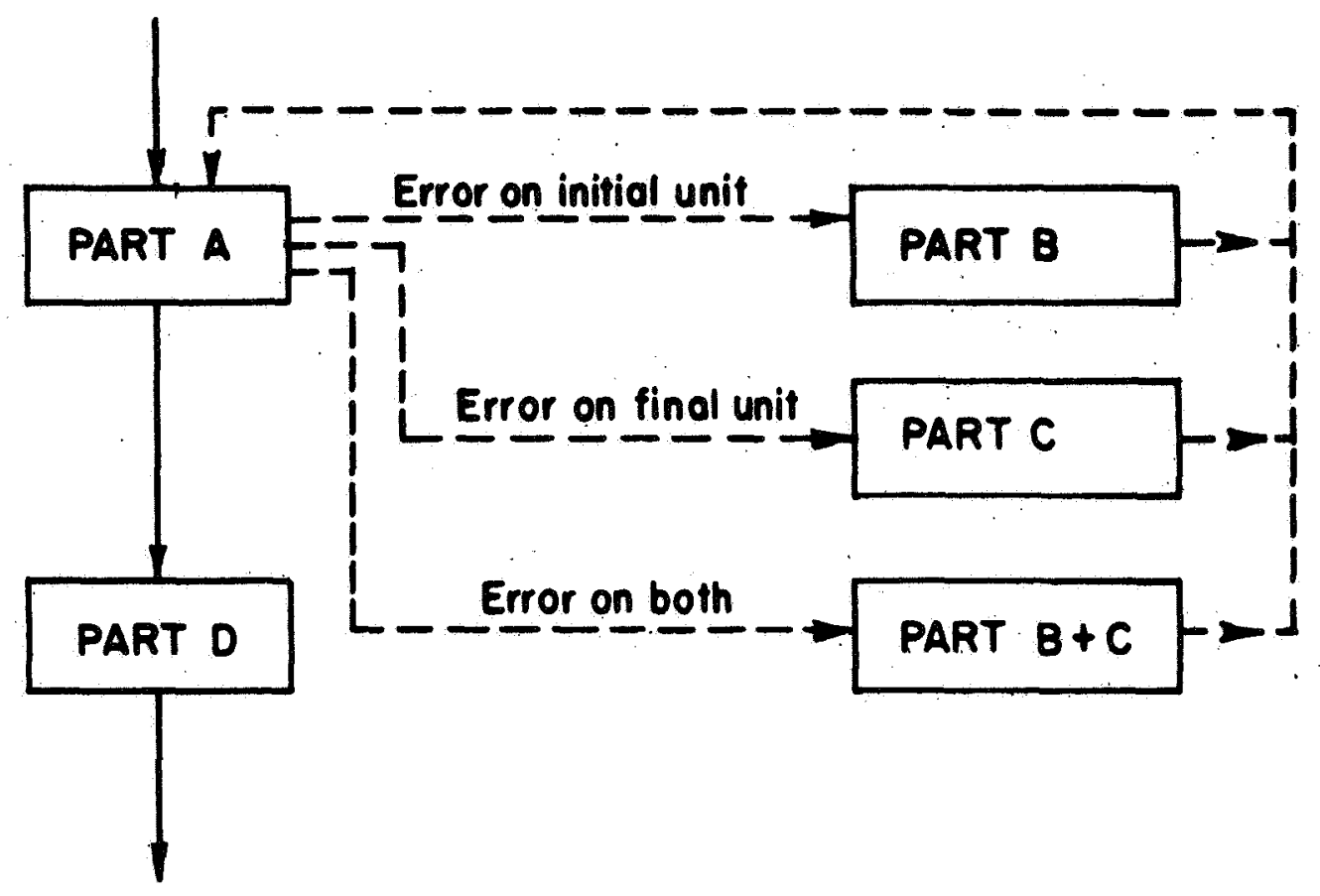

Flgure 2. Flow chart for the construction of a cell in the matrix construction task. 


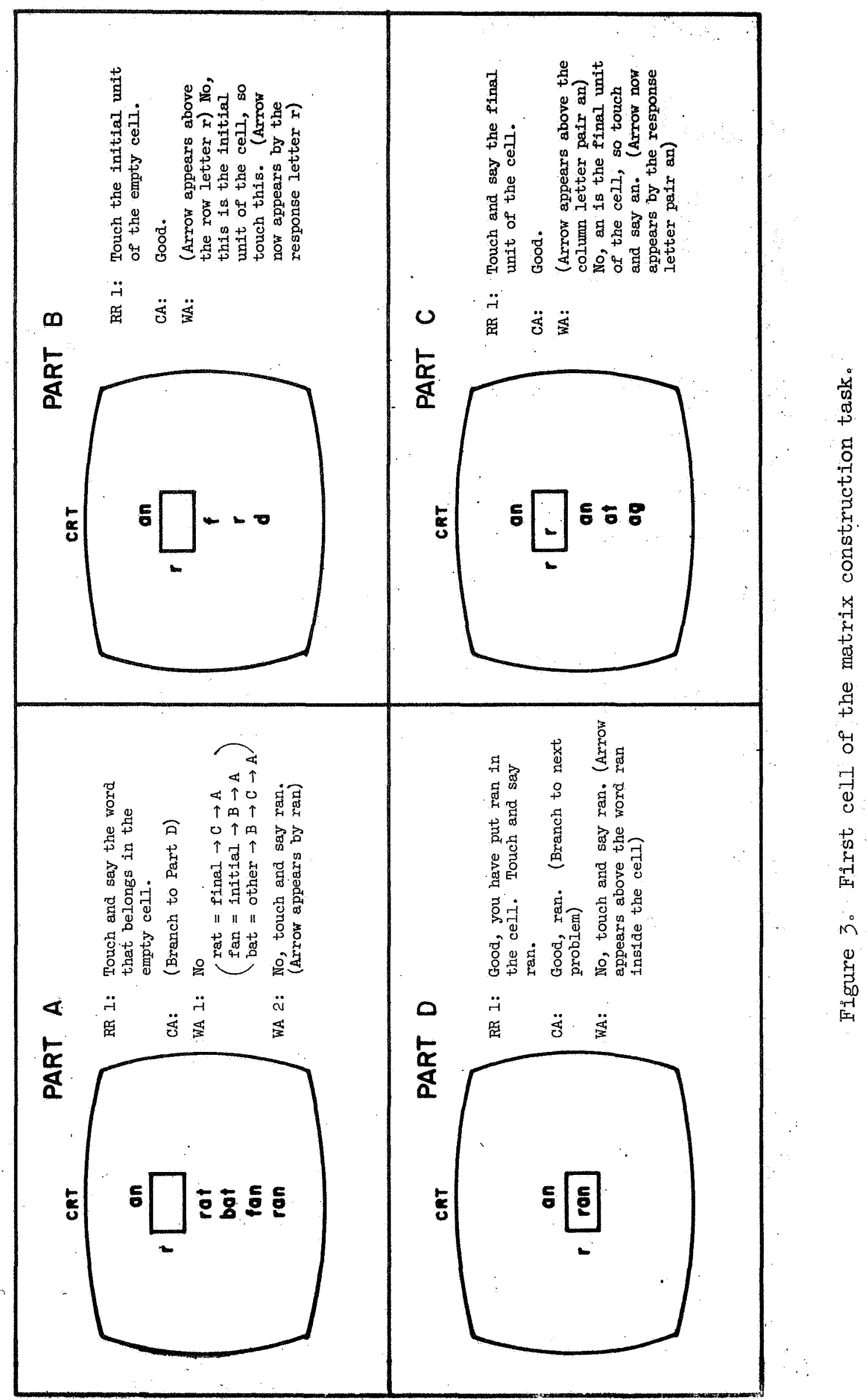




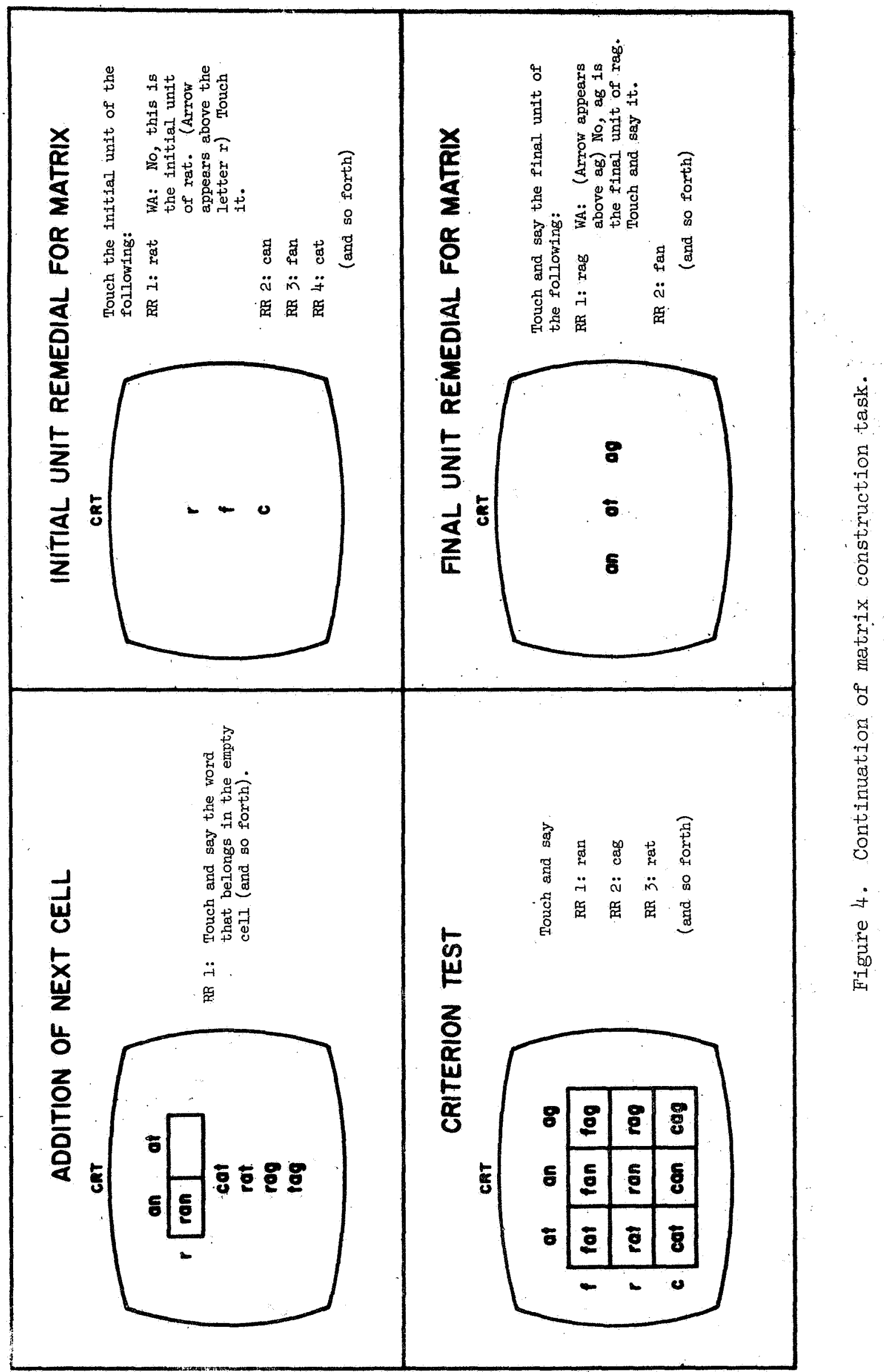


In the initial presentation in Part $A$, the array of multiple-choice responses is designed to identify three possible types of errors:

1) Initial unit correct; final unit incorrect.

2) Final unit correct; initial unit incorrect.

3) Both initial and final unit incorrect.

If, in Part $A$, the student responds with fan he is branched to remedial Part $B$ where attention is focused on the initial unit of the cell. If a correct response is made in Part $B$, the student is returned to Part $A$ for a second attempt. If an incorrect response (WA) is made in Part $B$, an arrow is displayed on the CRT to indicate the correct response which the student is then asked to touch.

If, in Part $A$, the student responds with rat, he is branched to remedial Part $C$ where additional instruction is given on the final unit of the cell. The procedure in Part $C$ is similar to Part Bo However, it should be noted that in the remedial instruction the initial letter is never pronounced by the audio system (Part B), whereas the final unit is always pronounced (Part $C$ ). If, in Part $A$, the student responds with bat, then he has made an error on both the initial and final unit and is branched through both Part B and Part C.

When the student returns to Part $A$ after completing a remedial section, a correct response will advance him to Part D as indicated. If a wrong answer response is made on the second pass, an arrow is placed beside the correct response area and held there until a correct response is made. If the next response is still an error, a message is sent to the proctor terminal and the sequence is repeated from the beginning. 
When a student has made a correct response on Parts $A$ and $D$, he is advanced to the next word cell of the matrix which has a problem format and sequence identical to that just described. The individual cell building is continued block by block until the matrix is complete. The upper left-hand panel of Figure 4 indicates the CRT display for adding the next cell in our example. The order in which row and column cells are added is essentially random.

When the matrix is complete, the rows and columns are reordered and a criterion test is given over all cell entries. The test involves displaying the full matrix as illustrated in the lower left-hand panel of Figure 4. Randomized requests are made to the student to identify cell entries. Since the first pass through the full matrix is viewed as a criterion test, no reinforcement is given. Errors are categorized as initial, final and other; if the percentage of total errors on the criterion test exceeds a predetermined value, then remedial exercises are provided of the type shown in the two right-hand panels of Figure 4 . If all the errors are recorded in one category (initial or final), only the remedial material appropriate to that category is presented. If the errors are distributed over both categories, then both types of remedial material are presented. After working through one or both of the remedial sections, the student is branched back for a second pass through the criterion matrix The second pass is a teaching trial as opposed to the Initial test cycle; the student proceeds with the standard correction and optimization routines.

This is only one example of the many different types of tasks used in the reading curriculum, but it indicates the nature of the studentsystem interaction. What is not illustrated by this example is the 
potential for long-term optimization policies based on an extended response history from the subject. We shall return to this topic later.

\section{Problems in Implementing the Curriculum}

Before turning to the data from last year's run, let me consider briefly the problem of translating the curriculum materials into a language that can be understood by the computer. The particular computer language we use is called Coursewriter II, a language which was developed by IBM in close collaboration with Stanford University. A coded lesson is a series of Coursewriter II commands which cause, the computer to display and manipulate text on the CRT, position and display film in the projector, position and play audio messages, accept and evaluate keyboard and light pen responses, update the performance record of each student, and implement the branching logic of the lesson flow by means of manipulating and referencing a set of switches and counters. A typical lesson in the reading program, which takes the average student about 30 minutes to complete, requires in excess of 9000 coursewriter commands for its execution.

A simple example will illustrate some of the complexities of the coding problem. The example is from a task designed to teach both letter discrimination and the meaning of words. A picture illustrating the word being taught is presented on the projector screen. Three words, including the word illustrated, are presented on the CRT. A message is played on the audio system asking the child to touch the word on the CRT that matches the picture on the film projector. The student can then make his response using the light pen. If he makes no response within the specified time limit of 30 seconds, he is told the correct answer, an arrow points to it, and he is asked to touch it. If he makes a response within the time Iimit, 
the point that he touches is compared by the computer with the correctanswer area. If he places the light pen within the correct area, he is told that he was correct and goes on to the next problem. If the response was not in the correct area, it is compared with the area defined as a wrong answer. If his response is within this area, he is told that it is wrong, given the correct answer, and asked to touch it. If his initial response was neither in the anticipated wrong-answer area nor in the correct-answer area, then the student has made an undefined answer. He is given the same message that he would have heard had he touched a defined wrong answer; however, the response is recorded on the data record as undefined. The student tries again until he makes the correct response; he then goes on to the next problem.

To prepare an instructional sequence of this sort, the programmer must write a detailed list of commands for the computer. He must also record on an audio tape all the messages the student might hear during the lesson in approximately the order in which they will occur. Each audio message has an address on the tape and will be called for and played when appropriate. Similarly a film strip is prepared with one frame for each picture required in the lesson. Each frame has an address and can be called for in any order. Table 1 shows the audio messages and film pictures required for two sample problems along with the hypothetical addresses on the audio tape and film strip. Listed in Table 2 are the computer commands required to present two examples of the problems described above, analyze the student's responses, and record his data record. The left column in the table lists the actual computer commands and the right column provides an explanation of each command. 
Table I

Audio Scrip and Film Chips with Hypothetical Addresses

Audio information
Address
A01: Touch and say the word that goes with the picture.
A02: Good. Bag. Do the next one.
A03: No.
A04: The word that goes with the picture is bag. Touch and
A05: Good. Card. Do the next one.
A06: No.
A07: The word that goes with the picture is card. Touch and
Fay card.
Film Strip
Address




\section{Computer Commands Required to Present Two Examples of the Problem Described in the Text}

Jumands

PK

I] $\mathrm{C} / \mathrm{SI}$

$\therefore 101$

I. $3,18 /$ bat/

1) $1,18 / \mathrm{bag} /$

i 9,18/rat/

AUI AOI

J.L $E \mathrm{~F} \quad 30 / A B C D 1$
AD $1 / C 4$
ID $1 / \mathrm{sI}$
AUP AO4

DT $7,16 /-7$

$\mathrm{R}$ LI

$\mathrm{CA} 1,7,3,18 / \mathrm{CI}$

$1 \mathrm{I} 2 / \mathrm{SL} / \mathrm{I}$

AI $1 / \mathrm{Cl}$

I2 Al: AO2

WA $1,5,3,18 / W 1\}$ WA $1,9,3,18 / \mathrm{W} 2\}$

\section{Explanation}

Problem: Prepares machine for beginning of new problem.

Load: Ioads zero into the error switch (SI). The role of switches and counters will be explained later.

Film Position: Displays frame FOl (picture of a bag).

Display Text: Displays "bat" on line 5 starting in column 18 on the CRT.

Displays "bag" on line 7 starting in column 18 on the CRT.

Displays "rat" on line 9 starting in column 18 on the CRT.

Audio Play: Plays audio message AOI. "Touch and say the word that goes with the picture."

Enter and Process: Activates the light-pen; specifies the time Iimit ( $30 \mathrm{sec}$ ) and the problem identifier ( $A B C D 1$ ) that will be placed in the data record along with all responses to this problem. If a response is made within the time limit the computer skips from this command down to the CA (correct answer comparison) command. If no response is made within the time limit, the commands immediately following the EP command are executed.

Add: Adds one to the overtime counter (c4).

Loads one into the error switch (SI).

Plays message AO4. "The word that goes with the picture is bag. Touch and say. bag."

Displays arrow on line 7, column 16 (arrow pointing at "bag").

Branch: Branches to command labeled LI. The computer will now do that command and continue from that point.

Correct Answer: Compares student's response with an area one line high starting on line 7 and three columns wide starting in column 18 of the CRT. If his response falls within this area, it will be recorded in the data with the answer identifier $\mathrm{Cl}$. When a correct answer has been made, the commands from here dow to WA (wrong answer comparison) are executed. Then the program jumps ahead to the next PR. If the response does not fall in the correct area, the machine skips from this command down to the WA command.

Branches to command labeled L2 if the error switch (SI) is equal to one.

Adds one to the initial correct answer counter (CI).

Plays audio message AO2. "Good. Bag. Do the next one."

Wrong Answer: These two commands compare the student response with the areas of the two wrong answers, that is, the area one line high starting on line 5 and three columns wide starting in column 18, and the area one line high starting on line 9 and three columns wide starting in column 18 . If the response falls within one of these two areas, it will be recorded with the appropriate identifier (W1 or W2). When a defined wrong answer has been made; the commands from here down to UN (undefined answer) are executed. Then the computer goes back to the EP for this problem. If the response does not fall in one of the defined wrong answer areas, the machine skips from this command down to the UN command. 
Commands

$\mathrm{AD} 1 / \mathrm{C} 2$

I3 ID 1/SI

AUP $\mathrm{AO} 3$

AUP $\mathrm{AO}_{4}$

DT $7,26 /-4$

UIV

AD $1 / \mathrm{C} 3$

BR I3

PR

ID $0 / \mathrm{SI}$

FP FO2

DT 5,I8/card/

DT $7,18 /$ cart/

DT 9,18/hard/

$\mathrm{I} 4 \mathrm{EP} 30 / \mathrm{ABCD} 2$

AD $1 / \mathrm{C} 4$

ID $I / S I$

AUP A07

DT $5,16 / \rightarrow$

BR I 4

CA $1,5,4,18 / \mathrm{C} 2$

BR I5/SI/I

AD $1 / C l$

I5 AUP AO5

WA $\left.1,7,4,18 / W_{3}\right\}$ WA $\left.1,9,4,18 / W_{4}\right\}$

$\mathrm{AD} 1 / \mathrm{C2}$

I6 ID $1 / \mathrm{SI}$

AUP A06

AUP AO7

DT $5,16 / \rightarrow$

UN

$\mathrm{AD} 1 / \mathrm{C} 3$

BR I6
Explanation

Adds one to the defined wrong answer counter (C2).

Ioads one into the error switch (SI).

Plays message A03. "No."

Plays message A04. "The word that goes with the picture is bag. Touch and say bag."

Displays arrow on line 7 , column 16.

Undefined Wrong Answer: If machine reaches this point in the program, the student has made neither a correct nor a defined wrong answer.

Adds one to the undefined answer counter (c3).

Branches to command labeled I3. (The same thing should be done for both UN and WA answers. This branch saves repeating the commands from L3 dow to UN.)

Prepares the machine for next problem.

These commands prepare the display for the 2nd problem. Notice the new film position and new words displayed. The student was told to "do the next one" when he finished the last problem so he needs no audio message to begin this.

\section{Light-pen is activated.}

These commands are done only if no response is made in the time limit of 30 seconds: Otherwise the machine skips to the CA command.

Compares response with correct answer area.

Adds one to the initial correct answer counter unless the error switch (SI) shows that an error has been made for this problem. The student is told he is correct and goes on to the next problem. These commands are executed only if a correct answer has been made.

Compare response with defined wrong answer.

Adds one to the defined wrong answer area and the error switch (SI) is loaded with one to show that an error has been made on this problem. The student is told he is wrong and shown the correct answer and asked to touch it. These commands are executed only if a defined wrong answer has been made.

An undefined response has been made if the machine reaches this command.

Adds one to the undefined answer counter and we branch up to give the same audio, etc. as is given for the defined wrong answer.

The use of macros greatly reduces the effort required to present different but basically similar problems. For example, the above two problems could be presented in macro format as follows:

Problem 1: CM PW]F01]bat]bag]rat]AO1]ABCD1]A04]A02]A03]7]1, 7,3,181C1]

Problem 2: .CM FW]FO2] card] cart lhard] ]ABCD2 ]A07]A05]A06] 5] 1, 5, 4, 18 ] C2]

The command to call a macro is $\mathrm{CM}$ and $\mathrm{PW}$ is an arbitrary two-character code for the macro involving a picture-to-word match. Notice that in problem 2 there is no introductory audio message; the "]]" indicates that this parameter is not to be filled in. 
While a student is on the system, he may complete as many as 5 to 10 problems of this type per minute. Obviously, if all of the instructional material has to be coded in this detail the task would be virtually impossible. Fortunately, there are ways of simplifying the coding procedure if parts of the instructional materials are alike in format and differ only in certain specified ways. For example, the two problems presented in Table 2 differ only in 1) the film display, 2) the words presented on the CRT, 3) the problem identifier for the student's data record, 4) the three audio messages, 5) the row display of the arrow, 6) the correctanswer area, and 7) the correct-answer identifier. This string of code can be defined once, given a two-letter name, and used later by giving a one-line macro command.

The use of macros cuts down greatly the effort required to present many different but basically similar problems. For example, the two problems presented in Table 2 can be rewritten in macro format using only two lines of code:

Problem 1: CM PW]FO1]bat]bag]rat]AO1]ABCD1] A04]AO2]AO3]7] 1,7,3, 18]Cl]

Problem 2: CM PW]FO2] card] cart] hard] ]ABCD2]A07]A05]A06]5]1, 5, 4, 18] C2] The command to call a macro is $\mathrm{CM}$ and $\mathrm{PW}$ is an arbitrary two-character code for the macro involving a picture-to-word match. Notice that in problem 2 there is no introductory audio message; the "]]" indicates that this parameter is not to be filled in.

The macro capability of the source language has two distinct advantages over code written command by command. The first is ease and speed of coding. The call of one macro is obviously easier than writing the comparable string of code. The second advantage is increase in accuracy. 
Not only are coding errors drastically curtailed, but if the macro is defective or needs to be changed, every occurrence of it in the lesson coding can be corrected by modifying the original macro; in general, the code can stay as it is. The more standard the various problem formats, the more valuable the macro capability becomes. Apart from a few nonstandard introductory audio messages and display items, approximately $92 \%$ of the reading curriculum has been programmed using about 110 basic macros.

As indicated in Table 2, a bank of switches and counters are defined in the computer that can be used to keep a running record on each student. There are a sufficient number of these registers so that quite sophisticated schemes of optimization and accompanying branching are possible. Thus, one is in a position to present a series of words and to optimize the number of correct responses to some stipulated criteria, for example, five consecutive correct responses for each of the words. Or one can select from an array of phrases choosing those phrases for presentation that have the greatest number of previous errors. As a consequence of these decisions, each student pursues a fundamentally different path through the reading materials.

Some Results from the First Year of Operation

The Stanford CAI Project is being conducted at the Brentwood School in the Ravenswood School District (East Palo Alto, California). There were several reasons for selecting this school. It had sufficient population to provide a sample of well over 100 first-grade students. The students were primarily from "culturaily disadvantaged" homes. And the 
past performance of the school's principal and faculty had demonstrated a willingness to undertake educational innovations.

Computerized instruction began in November of 1966 with half of the first-grade students taking reading via CAI and the other half, which functioned as a control group, being taught reading by a teacher in the classroom. The children in the control group were not left out of the project, for they took mathematics from the CAI system instead. The full analysis of the student data is a tremendous task which is still underway. However, a few general results have already been tabulated that provide some measure of the program's success.

Within the lesson material there is a central core of problems which we have termed main-line problems. These are problems over which each student must exhibit mastery in one form or another. Main-line problems may be branched around by successfully passing certain screening tests or they may be met and successfully solved, or they may be met with incorrect responses in which case the student is branched to remedial material. The first year of the project ended with a difference between the fastest and slowest student of over 4000 main-line problems completed. The cumulative response curves for the fastest, median and slowest students are given in Figure 5. Also of interest is the rate of progress during the course of the year. Figure 6 presents the cumulative number of problems completed per hour on a month-by-month basis again for the fastest, median and slowest student. It is interesting to note that the rate measure was essentially constant over time for the median and slow students, but showed a steady increase for the fast student. Whether this last result is unique to our particular curriculum, or will characterize CAI programs in general needs to be checked out in future research. 


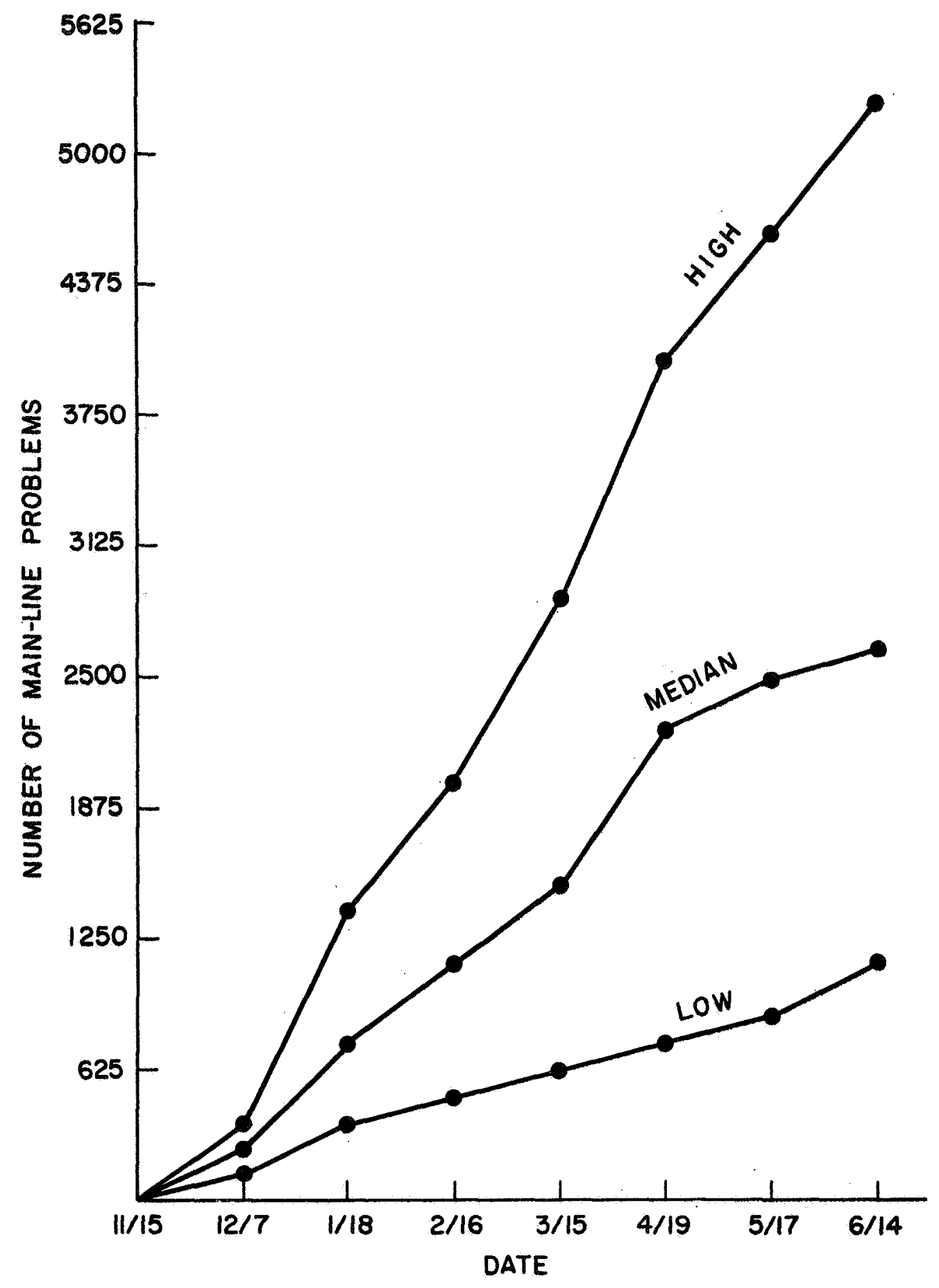

Figure 5. Cumulative number of main-line problems for fastest, median, and slowest student. 


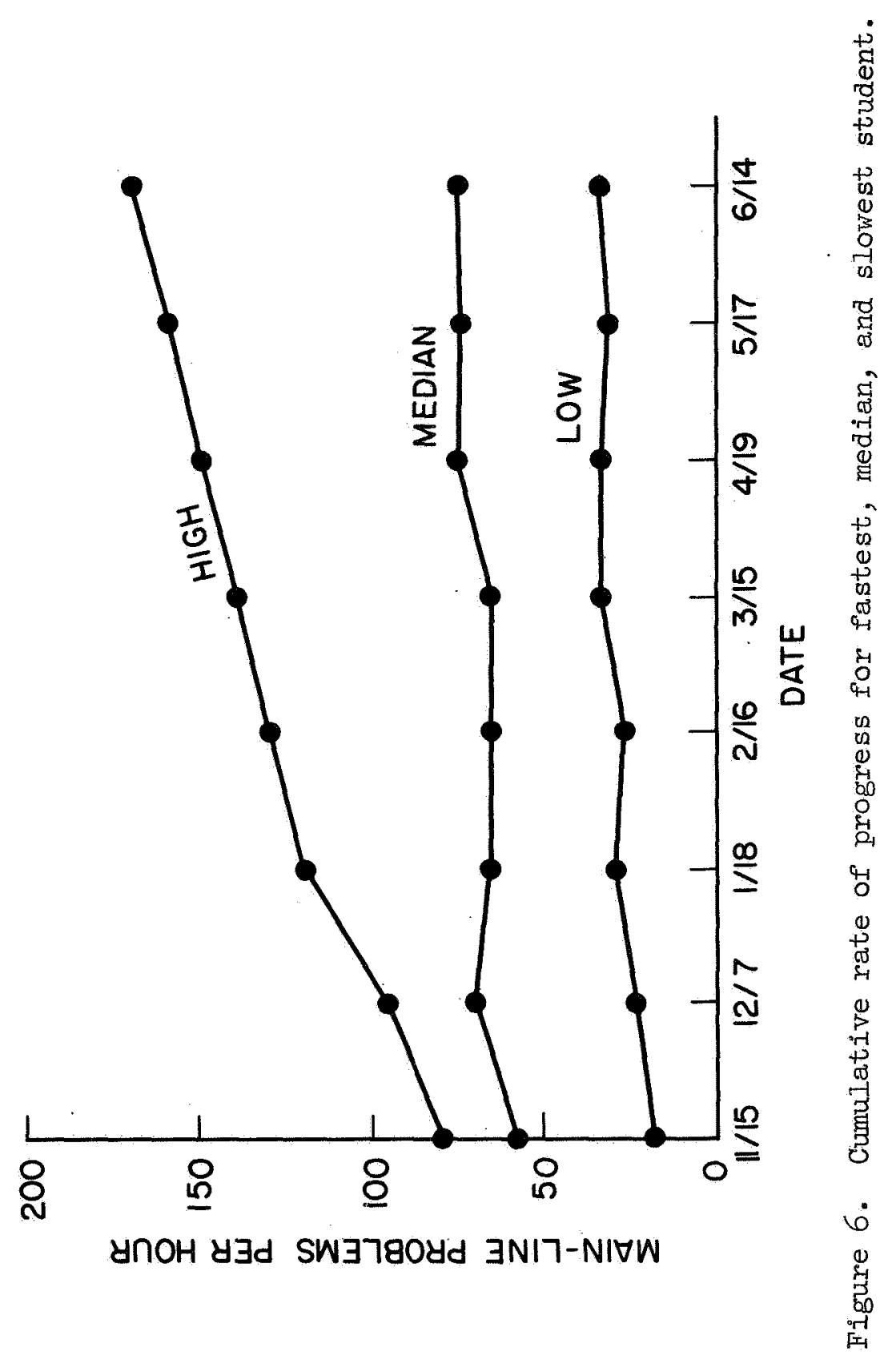


From the standpoint of both the total number of problems completed during the year and rate of progress, it appears that the CAI curriculum is responsive to individual differences. The differences noted above must not be confused with a variation in rate of response. The difference in response rate among students was very small. The average response rate was approximately four per minute and was not correlated with a student's rate of progress through the curriculum. The differences in total number of main-line problems completed can be accounted for by the amount of remedial material, the optimization routines, and the number of accelerations for the different students.

It has been a common finding that girls generally acquire reading skills more rapidly than boys. The sex differences in reading performance have been attributed, at least in part, to the social organization of the classroom and to the value and reward structures of the predominantly female primary grade teachers. It has also been argued on developmental grounds that first-grade girls are more facile in visual memorization than boys of the same age, and that this facility aids the girls in the sightword method of vocabulary acquisition commonly used in basal readers. If these two arguments are correct, then one would expect that placing students in a CAI environment and using a curriculum which emphasizes analytic skills as opposed to rote memorization, would minimize sex differences in reading. In order to test this hypothesis, the rate of progress scores were statistically evaluated for sex effects. The result, which was rather surprising, is that there was no difference between male and female students in rate of progress through the CAI curriculum. 
Sex differences however might be a factor in accuracy of performance. To test this notion the final accuracy scores on four standard problem types were examined. The four problem types, which are representative of the entire curriculum, were Letter Identification, Word List Learning, Matrix Construction, and Sentence Comprehension. On these four tasks, the only difference between boys and girls that was statistically significant at the 0.05 level was for word-list learning. These results, while by no means definitive, do lend support to the notion that when students are removed from the normal classroom environment and placed on a CAI program, boys perform as well as girls in overall rate of progress. The results also suggest that in a CAI environment the sex difference is minimized in proportion to the emphasis on analysis rather than rote memorization in the learning task. The one problem type where the girls achieved significantly higher scores than the boys, word-list learning, is essentially a paired-associate learning task.

As noted earlier, the first-graders in our school were divided into two groups. Half of them received reading instruction from the CAI system; the other half did not (they received mathematics instruction instead). Both groups were tested extensively using conventional instruments before the project began and again near the end of the school year. The two groups were not significantly different at the start of the year. Table 3 presents the results for some of the tests that were administered at the end of the year. As inspection of the table will show, the group that received reading instruction via CAI performed significantly better on all of the post-tests except for the comprehension subtest of the California Achievement Test. These results are most encouraging. Further, it should 
Table 3

Post-Tests Results for Experimental And Control Groups

\begin{tabular}{|c|c|c|c|}
\hline Test Type & Experimental & Control & p-value \\
\hline \multicolumn{4}{|l|}{ California Achievement Test } \\
\hline Vocabulary & 51.87 & 42.10 & $<.01$ \\
\hline Comprehension & 48.20 & 49.00 & $\ldots$ \\
\hline Total & 51.14 & 43.55 & $<.01$ \\
\hline \multicolumn{4}{|l|}{ Hartley Reading Test } \\
\hline Form Class & 11.22 & 9.00 & $<.05$ \\
\hline Vocabulary & 19.38 & 17.05 & $<.01$ \\
\hline Phonetic Discrimination & 30.88 & 25.15 & $<.01$ \\
\hline \multicolumn{4}{|l|}{ Pronunciation } \\
\hline Nonsense Word. & 6.03 & 2.30 & $<.01$ \\
\hline Word & 9.95 & 5.95 & $<.01$ \\
\hline \multicolumn{4}{|l|}{ Recognition } \\
\hline Nonsense Word & 18.43 & 15.25 & $<.01$ \\
\hline Word & 19.61 & 16.60 & $<.01$ \\
\hline
\end{tabular}


be noted that at least some of the factors that might result in a "Hawthorne Phenomenon" are not present here; the "control" group was exposed to CAI experience in their mathematics instruction. While that may leave room for some effects in their reading, it does remove the chief objection, since these students also had reason to feel that special attention was being given to them. It is of interest to note that the average Stanford-Binet $I_{\circ} Q$. score for these students (both experimental and control ) is 89. While considerable variation exists, these are, by and large, not exceptional or gifted children. ${ }^{3}$

Owing to systems and hardware difficulties, our program was not in full operation until late in November of 1966. Initially, students were given a relatively brief period of time per day on the terminals. This period was increased to 20 minutes after the first six weeks; in the last month we allowed students to stay on the terminal 30 to 35 minutes. We wished to find out how well first-grade students would adapt to such long periods of time. They adapt quite well, and next year we plan to use $30-$ minute periods for all students throughout the year. This may seem like a long session for a first-grader, but our observations suggest that their span of attention is well over a half hour if the instructional sequence is dynamic and responsive to their inputs. This year's students had a relatively small number of total hours on the system. We hope that by beginning in the early fall and using half-hour periods, we will be able to give each student at least 80 to 90 hours on the terminals next year.

\footnotetext{
3 More details on these and other analyses may be found in Wilson and Atkinson (1967)。
} 
I do not have time to discuss the social-psychological effects of introducing CAI into an actual school setting. There is a report on this topic, however, and it is fair to say in summary that the students, teachers, and parents were quite favorable to the program (Atkinson, 1967). Nor will time permit a discussion of some of the more interesting data dealing with the evaluation of various optimization routines that were used in this year's program. In some cases, these optimization procedures were based on sophisticated mathematical models of the learning processes involved, and yielded complex decision procedures that could. only be implemented using a computer. In other parts of the curriculum we selected procedures that were not based on learning-theoretic considerations, but were simply our best guess as to what we thought might be an optimal policy for making branching decisions among instructional materials. 4 Analyses of the data on optimal learning sequences have been informative and have suggested a number of experiments that need to be carried out this year. It is my hope that such analyses, combined with the potential for educational research under the highly controlied conditions offered by CAI, will lay the groundwork for a theory of instruction that is truly useful to the educator. Such a theory of instruction will have to be based on a highly structured model of the learning process, and must generate optimization strategies that are compatible with the goals of education. The development of a viable theory of instruction is a major scientific undertaking, but one that cannot be ignored much longer by psychologists. Substantial progress in this direction could well be one of psychology's most important contributions to society.

${ }^{4}$ The learning models and optimization methods that underlie much of the CAI reading program are discussed in Atkinson and Shiffrin (1968), Atkinson, Bower and Crothers (1965) and Groen and Atkinson (1966). 


\section{References}

Atkinson, R. C. Instruction in initial reading under computer control: the Stanford Project. Journal of Educational Data Processing, 1967, 4, in press.

Atkinson, $R_{0} C_{0}$, Bower, $G . H_{0}$ and Crothers, $E_{0} J$. An introduction to mathematical learning theory. New York: John Wiley and Sons, Inc., 1965.

Atkinson, R. C. and Hansen, D. N. Computer-assisted instruction in initial reading: the Stanford Project. Reading Research Quarterly, 1966, 2, $5-25$

Atkinson, R. C. and Shiffrin, R. M。 Human memory: a proposed system and its control processes. In $K$. W. Spence and $J . T$. Spence (Eds.), The psychology of learning and motivation: Advances in research and theory, Vol.2. New York: Academic Press, 1968, in press.

Fishman, Elizabeth J., Keller, L。 and Atkinson, R。 C. Massed vs. distributed practice in computerized spelling drills. Technical Report 117, Institute for Mathematical Studies in the Social Sciences, Stanford University, 1967.

Groen, G. J. and Atkinson, R. C. Models for optimizing the learning process, Psychological Bulletin, 1966, 66, 309-320.

Hansen, D. N. and Rodgers, T. S. An exploration of psycholinguistic units in initial reading. Technical Report 74 , Institute for Mathematical Studies in the Social Sciences, Stanford University, 1965. 


\section{References (Continued)}

Rodgers, T. S. Linguistic considerations in the design of the Stanford computer-based curriculum in initial reading. Technical Report 111, Institute for Mathematical Studies in the Social Sciences, Stanford University, 1967.

Suppes, $P_{0}$ The uses of computers in education. Scientific American, $1966,215,206-221$.

Suppes, P., Jerman, $M_{\circ}$ and Groen, $G_{*} J_{0}$ Arithmetic drills and review on a computer-based teletype. Arithmetic Teacher, April, 1966, 303-308.

Wilson, $H . A_{*}$ and Atkinson, $R_{*} C_{*}$ Computer-based instruction in initial reading: A progress report on the Stanford Project. Technical Report 119, Institute for Mathematical Studies in the Social Sciences, Stanford University, 1967. (To be published in Basic studies in reading, edited by $H$. Levin and Joanna Williams, New York: Harper and Row.) 


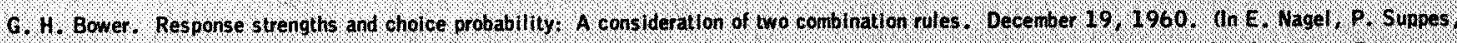

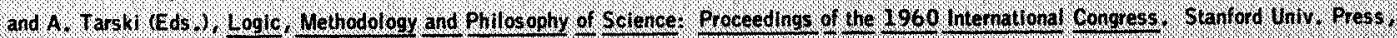
1962. $90.4(0-412)$

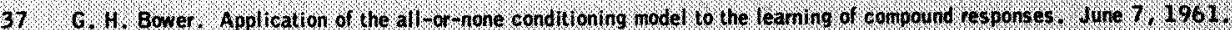

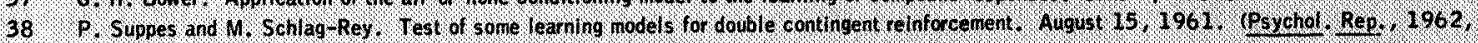

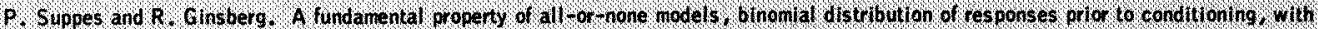

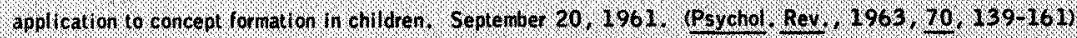

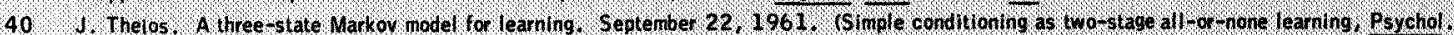
Rev. $1963,70,403-417$ )

41 G, M. Bower. General three-state Markov learning models. September 26,1961 .

42 R. C. Alkinson. A variable tireshold nodel tor signal detection. November $17,1961$.

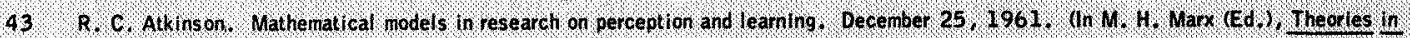
Contemporary Psychology, New York. Macmillan Co., 1963. Po, 551,564 )

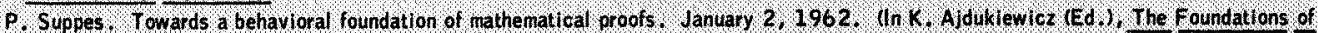
Statements and Decisions: Proceedings of the International Colloquilm on Methodology of Sclences, Seplember $18-23,1961$. Wars zawa PWN-Polish Sclentific Publishers, 1965, Pp, 327-341)

P. Suppes and J. L. Zinnes. Basic measurement theory. March 15,1962 . (Ghaptar 1 in R. R. Bush, E. H. Galanter, and R. D. Luce (Eds.) Handbook of Mathematical Psychology, Vol. 1. New York, John Wiley, 1963 )

R. C, Atkins on. E, C. Carterette, and R, A. KInchla. Sequential phenomena in psychophysical judgments, a theorelical analysis. April 20 . 1962. (Institute of Radio Engineers Transactions on Information Theory, 1962, $17-8,5155-162$ )

47 R. C. Atkins on, A variable sensitivity theory of signal detection. May 18, 1962, (Psychol, Rev, 1963, $10,91-106$ )

48 R. C. Atkins on and W. K. Estes. Stimulus sampling theory. July 1, 1962, (Chapter 10 in R, R. Bush, G. H. Galanter, and R, D. Luce (Eds.), Handbook of Mathematical Psychology, Vol, II. New York, Wiley, 1963)

49 P. Suppes, E. Crothers, R. Weir, and E. Trager. Some quantitative studies of Russian consonant phenome discrimination, September $14,1962$.

R. C. Atkinson and R. C. Calfee, Mathematical learning theory. January 2, 1963 , In B, B. Wolman (Ed,), Sclentifle Psychology. New York. Basic Books, Inc., 1965, Pp. 254-275)

P. Suppes, E. Crothers, and R. Weir. Application of mathematical learning theory and lingulstic analysis to vowel phoneme matching in Russian words. December $28,1962$.

R. C. Atkinson, R. Calfee, G. Sommer, W. Jeffrey and R. Shoemaker. A test of three models for stimulus compounding with children. January 29 , 1963. (J. exp. Psychol, $1964,67,52-58$ )

53 E. Crothers. General Markov models for learning with inter-trial forgetting. April 8, 1963

54 J. L. Myers and R. C. Atkinson. Choice behavior and reward structure. May 24, 1963 (Journal math. Psychol, 1964, $1,170-203$ )

55 R. E, Robinson. A set-theoretical approach to empirical meaningfulness of measurement statements. June $10,1963$.

56 E. Crothers, R. Weir and P. Palmer. The role of transcription in the learning of the orthographic representations of Russian sounds. June $17,1963$.

57 P. Suppes. Problems of optimization in learning a list of simple items. July 22, 1963. (In Maynard W. Shelly, II and Glenn L. Bryan (Eds.), Human Judgments and Optimality. New York. Wiley. 1964. Pp. 116-126)

58 R. C. Atkinson and E. J. Crothers. Theoretical notes all-or-none learning and intertrial forgetting. July $24,1963$.

59. R. C. Calfee, Long-term behavior of rats under probabilistic reinforcement schedules. October 1, 1963.

60 R. C. Atkinson and E.J. Crothers. Tests of acquisition and retention, axioms for paired-associate learning. October 25, 1963. (A comparison of paired-associate learning models having different acquisition and retention axioms, J. math. Psychol, $1964,1,285-315)$

61 W. J. McGill and J, Gibbon. The general-gamma distribution and reaction times. November 20, 1963, J. math, Psychol., 1965, 2, 1-18)

62 M. F. Norman. Incremental learning on random thals. December 9, 1963. U. math. Psychol, 1964, 1, 336-351)

63 P. Suppes. The development of mathematical concepts in children. February 25,1964 . Con the behavioral foundations of mathematical concepts. Monographs of the Soclety for Research In Child Development, $1965,30,60-96)$

64 P. Suppes. Mathematical concept formation in children. April 10, 1964. (Amer Psychologist, 1966, 21, 139-150)

65 R. C. Calfee, R. C. Atkinson, and T. Shelton, Jr. Mathematical models for verbal learning, August 21, 1964. In N, Wiener and J, P. Schoda (Eds), Cybernetics of the Nervous System, Progress in Brain Research. Amsterdam, The Netherlands: Elsevier Publishing Co, 1965. Pp. $333-349)$

L. Keller, M. Cole, C. J. Burke, and W, K. Estes. Paired associate learning with differential rewards. August 20, 1964. (Reward and Information values of trial outcomes in paired associate learning, (Psychol. Monogr, 1965, 79, 1-21)

67 M. F, Norman, A probabilistic nodel for free-responding, Decenber $14,1964$.

68 W. K. Estes and H. A. Taylor. Visual detection in relation to display size and redundancy of critical elements. January 25,1965, Revised 7-1-65. (Perception and Psychophysics, $1966,1,9-16$ )

69 P. Suppes and J. Donio. Foundations of stimulus -sampling theory for continuous - time processes, February 9,1965 .

70 R. C. Alkinson and R, A, Kinchla. A learning model for forced-choice detection experiments, February 10,1965, Br. J, math stat, Psychol., $1965,18,184-206)$

71. E. J, Crothers. Presentation orders for ltems from different categortes. March $10,1965$.

72 P. Suppes, G. Groen, and M. Schilag-Rey. Some models for response latency in paired-associates learning. May 5, 1965. U, math, Psychol. $1966,3,99-128)$

73 M. V. Levine. The generalization function in the probability learning experiment. June $3,1965$.

74 D. Hansen and T, S. Rodgers. An exploration of psychol inguistic units in initial reading, July $6,1965$.

B. C. Arnold. A correlated um-scheme for a continuum of responses, July $20,1965$.

C. Izawa and W, K. Estes. Reinforcenent-test sequences in paired-ass ociate learning. August 1, 1965. S. L. Blehart. Pattern discrimination learning with Rhesus nonkeys. September 1, 1965.

J. L. Phillips and R, C. Atkinson. The effects of display size on short-term memory. August 31, 1965.

R. C. Atkinson and R. M. Shiffin. Mathematical models for memory and learning, September $20,1965$.

P. Suppes. The psychological foundations of mathematics. October $25,1965$. 
81 P. Suppes. Computer-assisted instruction in the schools, potentialtiles, problems, prospects, 0ctober $29,1965$. R. A. Kinchla, J, Townsend, J, Yellotl, Jr, and R, C. Alkinson. Iniluence of conelated visual cues on auditory signal detection. November 2 , 1965. (Perception and Psychophysics, 1966, 1,67-73)

83 P. Suppes, M. Jerman, and G. Groen, Arithmetic dillis and revlew on a computer based weletype, November 5,1965 P. Suppes and L. Hyman. Concept learning with non-verbal geometrical stimull. Vovember 15,1965 .

P. Holland. A varlatlon on the minimum chl-square test. November 18,1965

P. Suppes. Accelerated program in elementary -school nathematics - the second year. Novenber $22,1965$.

P. Lorenzen and $F$. Binford, Logle as a dialogical game, November 29,1965

L. Keller, W, J. Thomson, J. R. Tweedy, and R, C. Atkinson, The eftects of reiniorcement interval on the acquisition of paired-associate responses. December $10,1960$.

89 J. 1. Yellott, Jr. Some effects on noncontingent success in human probability learning. Decenber $15,1965$.

90 P. Suppes and G. Groen. Some counting models for first-grade performance data on simple addition facts. January 14,1966 .

91 P. Suppes. Inlormation processing and choice behavio.. January $31,1966$.

92 G. Groen and R. C. Atkinson. Models for optimizing the learning process. February $11,1966$.

93 R. C. Alkins on and D. Hansen. Computer-assisted instruction in initial reading, Stanford project. March 17, 1966.

94 P. Suppes. Probabilistic inference and the concept of total evidence. March 23, 1966.

95 P. Suppes. The axiomatic method in high-school mathematics. Aprit $12,1966$.

96 R. C. Atkinson, J. W. Brelsford, and R. M. Shiffrin. Multi-process models for memory with applicatlons to a continuous presentation task. April 13, 1966 .

97 P. Suppes and E. Crothers, Some remarks on stimulus-response theories of language leanning. June 12,1966

98 R. Bjork. All-or-none subprocesses in the learning of complex sequences. June 22, 1966.

99 E. Gammon. The statistical determination of linguistic units. July 1, 1966.

100 P. Suppes, L. Hyman, and M. Jerman. Linear structural models for response and latency performance in arithmetic. July $29,1966$.

101 J. L. Young. Effects of intervals between reinforcements and test trials in paired-as sociate learning. August 1, 1966.

102. H. A. Wilson. An investigation of linguistic unit size in memory processes. August 3, 1966.

103 J. T. Townsend. Choice behavior in a cued-recognition task. August $8,1966$.

104 W. H. Batchelder. A mathematical analysis of multi-level verbal learning; August 9, 1966

105 H, A. Taylor. The observing response in a cued psychophysical task. August 10,1966.

R. A. Bjork. Learning and short-term retention of paired associates in relation to specific sequences of interpresentation intervals. August II, 1966 .

R. C. Atkins on and R. M. Shiffrin. Some Two-process models for memory, September 30, 1966.

P. Suppes and C. Inrke. Accelerated program In elementary-school mathematics--the third year. January 30, 1967

109 P. Suppes and I. Rosenthal-Hill. Concept formation by kindergarten children in a card-sorting task. February $27,1967$.

110 R C Atkinson and R. M Shiffrin. Human memory: a proposed system and its control processes. March 21, 1967

111 Theodore S, Rodgers. Linguistic considerations in the design of the Stanford computer-based curriculum in initial reading. June 1,1967

112 Jack M. Knutson. Spelling drills using a computer-assisted Instructional system. June 30, 1967.

113 R. C. Atkinson. Instruction in initial reading under computer control: the Stanford Project. July 14, 1967.

114 J.W. Brelsford, Jr, and R. C. Atkinson. Recall of paired-associates as a function of overt and covert rehearsal procedures. July 21,1967

$115 \mathrm{~J}$. H. Stelzer. Some results concerning subjective probability structures with semiorders. August $1,1967$.

116 D. E. Rumel hart. The effects of interpresentation intervals on performance in a continuous paired-associate task. August $31,1967$.

117 E. J. Fishman, L. Keller, and R.E. Atkinson. Massed vs. distributed practice in computerized spelling drills. Auqust 18.1967.

118 G. J. Groen. An investigation of some counting algorithms for simple addition problems. August $21,1967$.

119 H. A. Wilson and R. C. Atkinson. Computer-based instruction in initial reading: a progress report on the Stanford Project. August $25,1967$.

120 F.S. Roberts and P. Suppes. Some problems in the geometry of visual perception. August $31,1967$.

121 D. Jamison. Bayesian decisions under total and partial ignorance. D. Jamison and J. Kozieleckí. Subjective probabilities under total uncertainty. September 4, 1967.

122 R. C. Atkinson. Computerized instruction and the learning process. September 15, 1967. 